\section{Editing Latin American Antiquity in the Context of Global Changes}

$\mathrm{A}$ s prospective new coeditors of Latin American Antiquity (LAQ), on March 8, 2019, we found ourselves in the midst of the unbridled development and triumphant optimism of the Anthropocene, with governments, nongovernmental organizations, and many of the planet's inhabitants ignoring or disregarding the irreversible destruction of the Earth's ecosystems and its biodiversity, as well as the depletion or poisoning of vital resources such as water; added to this were their neglect and repression of social uprisings that demanded and still demand minimum guarantees of access to basic human rights, such as education, health, and work without discrimination or misguided postponements. We presented our proposal to become the next editorial team, never imagining that humanity was on the verge of a great global turning point, caused by a new virus, which suddenly and rapidly spread uncontrollably over the face of the Earth, causing death, destruction, and social and economic upheaval.

In this turbulent time - and perhaps because of the pandemic's upending of normality - systemic racism, racial injustice, and statesanctioned violence against Black, Latinx, and Indigenous people in the United States and Latin America have become a source of protest and soul searching by individuals and organizations. In response to the murders of George Floyd, Breonna Taylor, and so many other Black people, the editors of the Society for American Archaeology's four publications and The SAA Press wrote a statement, the text of which follows this editorial and is available on the SAA's website. We committed ourselves to making every effort to change the underrepresentation of Black, Indigenous, and other minority researchers in SAA publications, an aspiration that extends to all stages of knowledge production in the discipline, including teaching, mentoring, and combating structural inequality, as stated in part of that statement.

All of this recent historical context has meant that our original proposal, which highlighted the need to extend the geographic and temporal coverage of LAQ, is fully in line with the aspiration to connect archaeology with current sociocultural contingencies. We see archaeology as a way of investigating the past that is not limited to any particular time period or historical epoch. It can and should connect the past to the present, being mindful of the concerns and interests of those groups whose history we presume to document and interpret. Research that studies the societies that developed after European contact and colonization in Latin America or the Caribbean, which is classified as historical archaeology by some, is research we welcome, especially if it examines Indigenous or minority groups, such as Africans or Asians who became part of these societies through enslavement or voluntary immigration. What interests us is research that helps us understand the complex nature of colonial societies and of their legacy and that helps reconstruct how people lived before the onslaught of European expansion. We enthusiastically promote the inclusion of varied perspectives to strengthen the theoretical and interpretive content of LAQ, and we encourage researchers from throughout Latin America and the Caribbean to consider submitting the results of their research to LAQ. Authors should feel comfortable using their mother tongue, such as Spanish or Portuguese, as the normal vehicle for the transmission of knowledge on an equal footing with the English language. We especially encourage scholars who are working with communities or who situate their research in the areas of heritage and public archaeology to submit their work to this journal. 
We know that it is important to publish articles and reports showcasing a broad range of research approaches, including, but not limited to, excavation and survey reports. Given the fragility of the archaeological record, the timeconsuming process of fieldwork, its high cost, and the concerns of stakeholders, we believe that there are many ways to contribute to understanding the past. We would value scholarship that attempts to extract new information from existing collections and archives through, for example, applying scientific techniques to the analysis of archaeological materials or comparing newer with older bodies of artifacts. Studies that cross disciplinary boundaries, delve into the history of Latin American archaeology and its relationship to larger historical trends, or conduct community-based research are also welcome.

To support our efforts, we reorganized LAQ's Editorial Advisory Committee (EAC), integrating new and continuing members from Latin America, North America, the Caribbean, and Europe to emphasize both a sense of continuity and change that will provoke a synergy among the multiple specializations and perspectives represented by the 29 colleagues who make up the EAC. In addition to inviting people who represent a broad range of interests, we took special care to assemble a committee that is as balanced as possible in terms of gender. As we welcome the new members of EAC, we publicly acknowledge the contributors who have left the committee and whose support was key to the extraordinary editorial achievements of María Gutiérrez and Geoffrey Braswell-whom we invited to join the EAC to accompany and guide us in reaching the editorial goals outlined here, as well as others, as defined in their long editorial published in volume 31 , issue 2 , of LAQ.

With this inclusive vision of LAQ, we have decided that two colleagues will be in charge of the book review section. We want to take this opportunity to thank Oswaldo Chinchilla who fulfilled this role with great distinction. The new book review editors are María Auxiliadora Cordero (Ecuador, University of Pittsburgh) and John Hoopes (University of Kansas). They will oversee the reviewing of books published on South America (María Auxiliadora) and Mesoamerica, Central America, and the Caribbean (John). We hope to expand the journal's coverage to feature books from local publishers such as museums, universities, and research institutes to promote important research work that is often overlooked.

In conclusion, we believe that our editorial plans for LAQ must recognize the social, economic, cultural, and universal public health bottleneck that this pandemic has caused and contribute to our thinking about readjusting and moving toward more inclusive and egalitarian human life systems on the planet.

Julia A. Hendon and Calogero M. Santoro

\section{Edición de Latin American Antiquity en el contexto de los cambios globales}

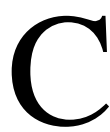

omo futuros nuevos coeditores de la Latin American Antiquity (LAQ), el 8 de marzo de 2019 nos encontramos en medio del desarrollo desenfrenado y el optimismo triunfante del Antropoceno, con gobiernos, organizaciones no gubernamentales y muchos de los habitantes del planeta ignorando o desatendiendo la destrucción irreversible de los ecosistemas de la tierra y su biodiversidad, el agotamiento o el envenenamiento de recursos vitales como el agua, sumado a la desatención y represión de los levantamientos sociales que exigían y siguen exigiendo garantías mínimas de acceso a derechos humanos básicos, como la educación, la salud y el trabajo, sin discriminación ni aplazamientos injustificados. Presentamos nuestra propuesta para ser el próximo equipo editorial, sin imaginar nunca que la historia de la humanidad estaba al borde de un gran giro global, causado por un nuevo virus, que se ha propagado repentina y rápidamente de forma incontrolada sobre la faz de la tierra, causando muerte, destrucción y trastornos sociales y económicos.

En esta época turbulenta $-\mathrm{y}$ tal vez debido a la alteración de la normalidad provocada por la pandemia - el racismo sistémico, la injusticia 
racial y la violencia permitida por el Estado contra los negros, los latinos y los indígenas en los Estados Unidos y América Latina se ha convertido en una fuente de protesta y de examen de conciencia para personas y organizaciones. En respuesta a los asesinatos de George Floyd, Breonna Taylor y tantos otros afroamericanos, los editores de las cuatro publicaciones y de la editorial de la Society for American Archaeology han escrito una declaración, cuyo texto sigue a esta editorial y está disponible en el sitio web de la SAA. Nos hemos comprometido a hacer todo lo posible por cambiar la escasa representación de los investigadores negros, indígenas y de otras minorías en las publicaciones de la SAA, una aspiración que se extiende a todas las etapas de la producción de conocimientos en la disciplina, incluida la enseñanza, la tutoría y la lucha contra la desigualdad estructural, como señala parte de dicha declaración.

Todo este contexto histórico reciente ha hecho que nuestra propuesta original, que ponía de relieve la necesidad de ampliar la cobertura geográfica y temporal de la LAQ, esté plenamente en consonancia con la aspiración de conectar la arqueología con las contingencias socioculturales actuales. Queremos destacar que vemos la arqueología como una forma de investigar el pasado que no se limita a ningún período de tiempo o época histórica en particular. Puede y debe conectar el pasado con el presente, teniendo en cuenta las preocupaciones e intereses de los grupos cuyas historias presumimos documentar e interpretar. La investigación que se ocupa de las sociedades que se desarrollaron después del contacto y la colonización europea en América Latina o el Caribe, que algunos clasifican como arqueología histórica, es una investigación que acogemos. Lo que nos interesa es investigación que contribuya a comprender la compleja naturaleza de las sociedades coloniales y su legado, así como la investigación que ayude a reconstruir cómo vivía la gente antes de la embestida de la expansión europea. Promovemos con entusiasmo la inclusión de variadas perspectivas para fortalecer el contenido teórico e interpretativo de la Revista. Alentamos a investigadores de toda América Latina y el Caribe a que consideren la posibilidad de presentar los resultados de sus investigaciones a LAQ. Los autores deben sentirse cómodos utilizando su lengua materna, como el español o el portugués, como vehículo normal para la transmisión de conocimientos, en igualdad de condiciones con el idioma inglés. Alentamos especialmente a los estudiosos que trabajan con comunidades o que sitúan sus investigaciones en las áreas del patrimonio y la arqueología pública a que presenten sus trabajos a la Revista.

Sabemos que es importante publicar artículos e informes que muestren una amplia gama de enfoques de investigación, incluyendo, pero no limitados a reportes de excavaciones y prospecciones arqueológicas. Dada la fragilidad del registro arqueológico, el largo proceso del trabajo de campo, su alto costo y las consideraciones de distintas partes interesadas, creemos que hay muchas maneras de contribuir a la comprensión del pasado. Valoramos los estudios que intentan extraer nueva información de colecciones y archivos existentes mediante, por ejemplo, la aplicación de técnicas científicas al análisis de materiales arqueológicos o la comparación de conjuntos de artefactos obtenidos más recientemente con los más antiguos. También son bienvenidas las investigaciones que crucen las fronteras disciplinarias, que profundicen en la historia de la arqueología latinoamericana y su relación con las tendencias históricas más amplias, o que realicen investigaciones basadas en la comunidad.

Para apoyar nuestros esfuerzos, hemos reorganizado el Comité Asesor Editorial (CAE) de la LAQ, integrando miembros nuevos y existentes de América Latina, América del Norte, el Caribe y Europa, para enfatizar un sentido tanto de continuidad como de cambio, que provoque una sinergia entre las múltiples especializaciones y perspectivas representadas en la lista de 29 colegas que conforman el CAE. Además de invitar a investigadores que representan una amplia gama de intereses, hemos tenido especial cuidado en reunir un comité lo más equilibrado posible en términos de género. Al dar la bienvenida a los nuevos miembros del CAE, reconocemos públicamente a los colaboradores que han dejado el Comité y cuyo apoyo ha sido clave para los extraordinarios logros editoriales de María Gutiérrez y Geoffrey Braswell. Hemos invitado a María y Geoff a unirse a la CAE, 
para que nos acompañen y nos guíen en los objetivos editoriales que aquí se exponen y otros definidos en su larga editorial publicada en el número 2 de este volumen 31 de LAQ, 2020.

Con esta visión inclusiva de LAQ, hemos decidido que dos colegas se encarguen de la sección de revisión de libros. Aprovechamos esta oportunidad para agradecer a Oswaldo Chinchilla, que cumplió este rol con gran distinción. Los nuevos editores de las reseñas de libros son María Auxiliadora Cordero (Ecuador, Universidad de Pittsburgh) y John Hoopes (Universidad de Kansas). Ellos supervisarán la revisión de los libros publicados en Sudamérica (María Auxiliadora) y Mesoamérica, Centroamérica y el
Caribe (John). Esperamos ampliar la cobertura de la Revista para incluir libros de editoriales locales, como museos, universidades e institutos de investigación, a fin de promover una importante labor de investigación que a menudo se pasa por alto.

En resumen, creemos que nuestros planes editoriales para LAQ deben reconocer el cuello de botella social, económico, cultural y de salud pública universal que esta pandemia ha causado, y deben contribuir a la necesidad de pensar en reajustar y avanzar hacia sistemas de vida humana más incluyentes e igualitarios en el planeta.

Calogero M. Santoro y Julia A. Hendon 